MS. ELISABETH BALLARD WARD (Orcid ID : 0000-0002-5195-5523)

DR. RICHARD A HALLETT (Orcid ID : 0000-0001-8462-8273)

DR. EMILY E OLDFIELD (Orcid ID : 0000-0002-6181-1267)

DR. MARK ALEXANDER BRADFORD (Orcid ID : 0000-0002-2022-8331)

Article type : Articles

Journal: Ecological Applications

Manuscript type: Article

Running head: Urban afforestation and soil restoration

\title{
Positive long-term impacts of restoration on soils in an experimental urban forest
}

Elisabeth B. Ward ${ }^{1,5}$, Danica A. Doroski ${ }^{1}$, Alexander J. Felson ${ }^{2}$, Richard A. Hallett ${ }^{3}$, Emily E. Oldfield $^{1}$, Sara E. Kuebbing ${ }^{4}$, Mark A. Bradford ${ }^{1}$

${ }^{1}$ The Forest School, School of the Environment, Yale University, New Haven, CT 06511, USA ${ }^{2}$ Melbourne School of Design, The University of Melbourne, Parkville, VIC 3010, Australia ${ }^{3}$ USDA Forest Service, Northern Research Station, Durham, NH 03824, USA

${ }^{4}$ Department of Biological Sciences, University of Pittsburgh, Pittsburgh, PA 15260, USA

${ }^{5}$ Corresponding author. E-mail: elisabeth.ward@yale.edu

Manuscript received 4 August 2020; revised 15 December 2020; accepted 15 January 2021.

This article has been accepted for publication and undergone full peer review but has not been through the copyediting, typesetting, pagination and proofreading process, which may lead to differences between this version and the Version of Record. Please cite this article as doi: 10.1002/EAP.2336

This article is protected by copyright. All rights reserved 


\section{Abstract}

As urbanization increases worldwide, so too are investments in nature-based solutions that aim to mitigate urban stressors and counter the impacts of global climate change. Tree planting on degraded urban lands - or afforestation - is one form of nature-based solution that has been increasingly implemented in cities around the world. The benefits of afforestation are, however, contingent on the capacity of soils to support the growth of planted trees, which poses a challenge in some urban settings where unfavorable soil conditions limit tree performance. Soil-focused site treatments could help urban areas overcome impediments to afforestation, yet few studies have examined the long-term ( $>5$ years) effects of site treatments on soils and other management objectives. We analyzed the impacts of compost amendments, interplanting with shrubs, and tree species composition (six species vs. two species) on soil conditions and associated tree growth in 54 experimental afforestation plots in New York City, USA. We compared baseline soil conditions to conditions after six years and examined changes in the treatment effects from one to six years. Site treatments and tree planting increased soil microbial biomass, water holding capacity, and total carbon and nitrogen and reduced soil $\mathrm{pH}$ and bulk density relative to baseline conditions. These changes were most pronounced in compost-amended plots, and the effects of the shrub and species composition treatments were minimal. In fact, compost was key to sustaining long-term changes in soil carbon stocks, which increased by $17 \%$ in compost-amended plots but declined in unamended plots. Plots amended with compost also had 59\% more nitrogen than unamended plots, which was associated with a 20\% increase in the basal area of planted trees. Improvements in soil conditions after six years departed from the initial trends observed after one year, highlighting the importance of longer-term studies to quantify restoration success. Altogether, our results show that site treatments and tree planting can have long-lasting impacts on soil conditions and that these changes can support multiple urban land management objectives.

\section{Keywords}

Afforestation; Carbon; Compost; Nature-based solutions; Nitrogen; Plant-soil interactions; Soil carbon stocks; Soil health; Urban forestry 


\section{Introduction}

Land-use change from urban and agricultural expansion is the leading driver of terrestrial biodiversity decline and loss of ecosystem services (IPBES, 2019). Seventy-five percent of the global land surface has been significantly altered by human use (IPBES, 2019), and projections of urban expansion predict continued and sustained growth at the expense of forests and other natural areas (Seto et al., 2012; Güneralp and Seto, 2013). The expansion of urban areas has been linked to significant losses in habitat, biodiversity, and carbon (C) storage (McKinney, 2002, Seto et al., 2012; IPBES, 2019), prompting investments in nature-based solutions (i.e., conservation or restoration practices that support ecosystem services, such as $\mathrm{C}$ storage and greenhouse gas emission reductions) to offset these negative impacts (Pataki et al., 2011; Griscom et al., 2017).

Globally, reforestation efforts - including afforestation of non-forested land — are suggested to offer one of the largest opportunities for low-cost, nature-based climate mitigation (Griscom et al., 2017; Doelman et al., 2019). As such, large-scale tree planting programs have become increasingly common in cities around the world (Pincetl et al., 2013). Once established, urban forests provide a multitude of social and ecological services and functions, such as $\mathrm{C}$ storage and sequestration (Nowak and Crane, 2002; Pataki et al., 2011), habitat for native wildlife (MacKay et al., 2011), stormwater mitigation (Xiao et al., 1998; Kuehler et al., 2017; Phillips et al., 2019), local cooling (Loughner et al., 2012), and a host of social, health, and aesthetic benefits (Tyrväinen et al., 2005; McPhearson, 2011; Elmqvist et al., 2015). However, the capacity of afforestation projects to fulfill these management goals hinges on whether planted trees ultimately mature into forests that can perform a broad range of ecological functions.

Although trees are the primary focus of afforestation projects, soils are also critical to achieving restoration goals. In addition to supporting the growth and development of planted trees (Hawver and Bassuk, 2007), healthy soils can help mitigate urban stressors by improving infiltration of excess stormwater (Phillips et al., 2019), retaining nutrients from run-off (Morel et al., 2015), sequestering and storing $\mathrm{C}$ in belowground pools (Pouyat et al., 2002), and promoting native understory plant recruitment over invasive species (Pavao-Zuckerman, 2008). However, urban soils can also be comprised of human-transported materials (e.g., topsoil relocation) and/or anthropogenic fill (Effland and Pouyat, 1997), which are characterized by high levels of compaction, unfavorable $\mathrm{pH}$ 
values (e.g., extremely acidic in former industrial sites or highly basic from the weathering of impervious surfaces), and insufficient nutrients to support tree growth and forest development (Capra et al., 2015). Restoration site treatments specifically designed to ameliorate soil conditions may therefore be required to support urban land management objectives at sites with anthropogenic soils.

In some circumstances, afforestation alone may be sufficient for improving soil conditions at degraded sites. For instance, afforestation has been shown to significantly increase soil organic C stocks - one of the most commonly used indicators of soil health (Bünemann et al., 2018) — in highly managed systems, such as former agricultural lands (Laganière et al., 2010), mines (Giménez et al., 2002), landfills (Schwendenmann and Mitchell, 2014), and wastelands (Shi and Cui, 2010). Likewise, in urban areas, afforestation can reduce compaction and build soil organic matter pools (Cao et al., 2007). Yet the potential benefits of urban afforestation are only attainable if planted trees overcome initial impediments to their survival and growth. This poses a challenge in some urban settings where inhospitable soil conditions severely limit tree performance (Jim, 1998b; Jim, 1993), including for native species (Pregitzer et al., 2016).

In recognition of these barriers to the success of urban afforestation projects, there is a growing body of research that seeks to understand how site treatments can be tailored to generate urban soil conditions that better support tree growth and other management objectives (e.g., Cogger, 2005; Layman, 2010; Oldfield et al., 2014). For instance, tillage practices can initially improve water holding capacity by decreasing compaction (Oldfield et al., 2014) which, in turn, can increase the root volume of planted trees (Layman, 2010). However, heavy tillage is also known to reduce soil C (Six et al., 2000; Haddaway et al., 2017), which poses a potential tradeoff with respect to urban land management objectives. Mulching, ground covers (Wang et al., 2017), and nurse shrubs (GómezAparicio et al. 2005) can also improve soil characteristics by regulating soil temperature, increasing soil moisture, and providing a source of $\mathrm{C}$ and nutrients to support microbial activity and plant growth. The addition of compost in the form of green waste or biosolids also has well-documented positive impacts on soil conditions (Chen et al. 2013; Chen et al. 2014) and, consequently, on the growth rates of planted trees over both short (Guerrini et al., 2017; Sullivan et al., 2005) and long (Layman et al., 2016) periods of time. Altogether, these findings suggest that soil-focused site treatments could help promote forest development. However, few studies have empirically tested the 
effects of different site treatments on soil conditions and tree growth over longer timeframes $(>5$ years; Kuebbing et al. 2018) and within the context of multiple management objectives. As planted trees take several years to respond to soil conditions (Brunner et al., 2015), and soil C stocks take years to accumulate post-planting (Li et al., 2012; Nave et al., 2013), evaluating longer-term changes in soil conditions and tree growth is essential for documenting the value of investments in tree planting projects and ensuring that this value translates into management practices.

Here, we help to fill this knowledge gap by assessing changes in soil physical, chemical, and biological properties and processes six-years after the implementation of site treatments and tree planting at a large-scale afforestation project in New York City, USA. We evaluated soil responses to three commonly used site treatments: compost amendments, interplanting with shrubs, and the species composition of planted trees. Specifically, we ask: (Q1) To what extent do the different site treatments alter soil conditions and belowground $\mathrm{C}$ stocks after six years relative to baseline conditions? (Q2) How do the effects of the site treatments on soils change over time? (Q3) Are changes in soil conditions resulting from site treatments associated with the growth of the planted trees? By evaluating the effects of site treatments and tree planting on soil conditions, along with the capacity of altered soils to fulfill specific management objectives, we aim to inform the design and implementation of future urban afforestation efforts.

\section{Methods}

\subsection{Site description and experimental design}

Our study was conducted within long-term research plots located in Kissena Corridor Park, a 40-ha urban park in Queens, New York, USA ( $40^{\circ} 44^{\prime} \mathrm{N}, 7^{\circ}{ }^{\circ} 49^{\prime} \mathrm{W}$; Fig. 1a). Kissena Corridor Park was planted as part of MillionTreesNYC, a citywide initiative established in 2007 to increase New York City's canopy cover (PlaNYC Reforestation Overview, 2015). Over the course of eight years, MillionTreesNYC planted one million trees throughout the city's natural areas and street tree pits (PlaNYC Reforestation Overview, 2015). To track the long-term effects of MillionTreesNYC, 54 experimental plots - collectively known as the New York City Afforestation Project (NY-CAP) were installed in Kissena Corridor Park in 2010 (Fig. 1b; Felson et al., 2013). The plots were intentionally established within a heavily-trafficked urban park to facilitate both research and public 
use (Felson et al., 2013). The experimental site has a moist temperate climate with temperature highs and lows in July (mean $24.9^{\circ} \mathrm{C}$ ) and January (mean $0.2^{\circ} \mathrm{C}$ ), respectively, and a mean annual precipitation of $109 \mathrm{~cm}$ (NOAA, 2018). The soils are classified as Laguardia-Ebbets complex, which is characterized by coarse, well-drained sandy loam with more than $10 \%$ human-transported material (NRCS, 2016). Parent material at Kissena Corridor Park is comprised of human-transported material which distinguishes the soils at our site from other urban soils of glacial origin (e.g., gneiss, granite, or schist) in this region.

The NY-CAP experimental plots test the impacts of three common site treatments (hereafter referred to as "experimental treatments") on planted tree growth (Oldfield et al., 2015) and soil conditions (Oldfield et al., 2014) over time: tree species composition (two species or six species), compost addition (compost-amended or unamended), and interplanting with shrubs (presence or absence; Felson et al., 2013). All 54 plots were randomly planted with either two or six tree species (i.e., the species composition treatment) in pairs of two plots, and each pair was treated with or without compost in a crossed arrangement (Fig. 1). Within each pair, one plot was interplanted with shrubs and one contained no shrubs (Fig. 1). Replication of the eight treatment combinations is uneven and as follows: two species/+ shrub/+ compost $(n=5)$, two species/+shrub/-compost $(n=9)$, two species/-shrub/+compost $(n=5)$, two species/-shrub/-compost $(n=9)$, six species/+shrub/+compost $(n=8)$, six species/+shrub/-compost $(n=5)$, six species/-shrub/+compost $(n$ $=8)$, and six species/-shrub/-compost $(n=5)$.

Prior to planting and plot installation, the site was dominated by invasive herbaceous species, such as Artemisia vulgaris L. (common mugwort) and native species, such as Solidago canadensis L. (Canada goldenrod; Oldfield et al. 2014). There were also a few small stands of Robinia pseudoacacia L. (black locust), Rhus typhina L. (staghorn sumac), Prunus serotina Ehrh. (black cherry), and a few individual Acer saccharinum L. (silver maple) located on the east side of the park but outside of the afforestation plots (see Fig. 1a). In 2009 all existing vegetation was removed from the planting area and plots were rototilled to prepare the site for planting (hereafter referred to as "site preparation"). This included the removal of brush, vines, stumps, roots, stones, human artifacts (e.g., concrete, scrap metal), and some trees $\leq 15 \mathrm{~cm}$ in diameter at $1.37 \mathrm{~m}$. At this time, compost was incorporated into the compost-amended plots $(n=26)$ to a depth of $15 \mathrm{~cm}$ at a rate of $2.5 \mathrm{~m}^{3}$ per 100 
$\mathrm{m}^{2}$ using a rototiller. The compost consisted of a commercial blend of nutrient-rich biosolids and clean, ground wood chips and had a $\mathrm{pH}$ of 6.3 , a bulk density of $0.457 \mathrm{~g} \mathrm{~cm}^{-3}$, and elemental concentrations of $60 \% \mathrm{C}, 3.2 \% \mathrm{~N}, 3.7 \% \mathrm{P}$ and $0.44 \% \mathrm{~K}$ on a dry weight basis (Oldfield et al., 2014). In 2010, all 54 plots also received a 5-cm surface layer of mulch composed of shredded hardwood trees to minimize drought stress for the planted trees. The $\mathrm{pH}$ of the mulch was between 5.8 and 7 , but the nutrient concentrations are unknown.

Native trees, shrubs, and forbs were planted in the NY-CAP plots in October 2010 following site preparation. All 54 15-m by 15-m plots were planted with 56 3- to 5-year-old container-grown $(7.58 \mathrm{~L})$ saplings that were 0.6 to $1.2 \mathrm{~m}$ in height. Trees were planted at a spacing of $2.1 \mathrm{~m}$ in an offset grid designed to integrate the research plots into the public landscape (Fig. 1; Felson et al., 2013). The plots were either planted with two or six species for the species composition treatments. Two-species plots $(n=28)$ included 28 Tilia americana L. (American basswood) and 28 Quercus rubra L. (northern red oak; Fig. 1b). Six-species plots $(n=26)$ included eight T. americana, eight $Q$. rubra, ten Celtis occidentalis L. (hackberry), ten P. serotina, ten Quercus alba L. (white oak), and ten Carya Nutt. species (hickory). The two sides of the park were planted with different but functionally similar Carya species owing to limited nursery availability; C. glabra (P. Mill.) Sweet (pignut hickory) was planted on the west side and C. laciniosa (Michx. F.) G. Don (shellbark hickory) was planted on the east side (Fig. 1). Half the plots $(n=27)$ were also underplanted with an assemblage of native shrubs (41 individuals/plot) and forbs (672 individuals/plot) in addition to the trees (Fig. 1b). We refer to this as the "shrub" treatment since the forb plantings suffered from high mortality oneyear post-planting and are therefore unlikely to affect long-term soil conditions. Shrub species included Sambucus nigra L. ssp. canadensis (L.) R. Bolli (American black elderberry), Hamamelis virginiana L. (American witch hazel), Lindera benzoin (L.) Blume (northern spicebush), Cornus racemosa Lam. (gray dogwood), and Viburnum dentatum L. (southern arrowwood; Fig. 1b). See Felson et al. (2013) for additional information on the design and set-up of NY-CAP and Oldfield et al. (2014) for the sourcing and selection of native plant materials.

\subsection{Soil sampling}

This article is protected by copyright. All rights reserved 
We sampled soils four times over the course of the experiment to capture baseline conditions in October 2009 (prior to site preparation and planting), conditions post-site preparation (prior to planting) in October 2010, and conditions one- and six-years post-planting in October 2011 and 2016, respectively. Our study supplements the results from the first three years of the project (i.e., 20092011; Oldfield et al., 2014) with data collected six-years post-planting in 2016 to assess whether the effects of the experimental treatments on soils were sustained over longer timeframes.

For each sampling occasion we collected and pooled five 8-cm diameter soil cores from the four corners and center of a smaller 10 by $10-\mathrm{m}$ area nested within the $15-\mathrm{m}$ by $15-\mathrm{m}$ research plots to minimize the influence of edge effects (Fig. 1b). We intentionally sampled from the same locations each year ( $\sim 50 \mathrm{~cm}$ from the base of the planted trees) to capture the effects of the growing trees (e.g., root expansion, leaf litter inputs) on soils over time. In 2009, 2010, and 2016, we sampled soils at two depths $(\sim 0-8 \mathrm{~cm}$ and $8-16 \mathrm{~cm})$ and recorded the exact depth to calculate $\mathrm{C}$ stocks to a fixed soil mass since we anticipated changes in bulk density owing to site preparation practices such as tilling (i.e., the cumulative mass coordinate approach in Gifford and Roderick, 2003). We had planned to collect soils to a cumulative depth of $30 \mathrm{~cm}$ but were unable to sample below $16 \mathrm{~cm}$ owing to extreme subsurface compaction. In 2011, we only collected 8-cm deep soil samples since we did not measure soil $\mathrm{C}$ stocks that year. We pooled all samples by depth (i.e., $0-8 \mathrm{~cm}$ or $8-16 \mathrm{~cm}$ ) and plot to minimize the influence of fine-scale (i.e., within-plot) heterogeneity on the laboratory measurements. This sampling scheme yielded 54 surface $(0-8 \mathrm{~cm})$ and 54 subsurface $(8-16 \mathrm{~cm})$ samples per year (with the exception of 2011) for a total of 378 samples. We kept soils in coolers following collection and returned them to the lab the same day, where they were stored as field-moist samples in sealed plastic bags at $4^{\circ} \mathrm{C}$ for up to 8 weeks prior to analysis.

\subsection{Planted tree measurements}

In August 2011, approximately ten months after planting, we took measurements for 24 trees planted in each of our experimental plots $(1,296$ trees total). These 24 trees were located in the center of the full $15-\mathrm{m}$ by $15-\mathrm{m}$ plot, allowing for a $2.5-\mathrm{m}$ buffer around plot edges (Fig. 1b). Initially the planted trees ranged from 0.6 to $1.2 \mathrm{~m}$ in height, so they were too small to measure diameter at breast height (DBH, $1.37 \mathrm{~m}$ ). Instead, we measured diameter of root collar (DRC) at soil level using calipers 
(Oldfield et al. 2015), which can be used in lieu of DBH measurements for small statured or multistemmed trees (Chojnacky and Rogers, 1999; Magarik et al., 2020). We remeasured these same planted trees in 2016. Six-years post-planting the trees were large enough to have a DBH, so we measured DBH instead of DRC and used the DBH measurements to calculate basal area $\left(\mathrm{m}^{2} \mathrm{ha}^{-1}\right)$. For trees with multiple stems we used the DBH of the largest stem for basal area calculations.

\subsection{Laboratory analyses}

For the 54 surface soil samples (i.e., $0-8 \mathrm{~cm}$ ) collected each year, we measured six soil variables indicative of particular ecological functions in temperate urban forests in our study region: bulk density, soil $\mathrm{pH}$, water holding capacity, active microbial biomass, and total $\mathrm{C}$ and nitrogen $(\mathrm{N})$ concentrations. For the 2016 surface samples, we also measured soil texture. For the 54 subsurface samples (i.e., 8-16 cm) collected in 2009, 2010, and 2016, we repeated bulk density and total C concentration measurements to calculate belowground $\mathrm{C}$ stocks on a per mass basis (Gifford and Roderick, 2003).

We weighed and homogenized each sample and air-dried a representative subsample of nonsieved soil $(\sim 500 \mathrm{~g})$ to determine the mass and volume of roots and stones greater than $2 \mathrm{~mm}$. We

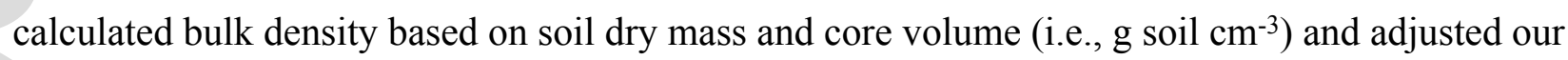
calculations for the mass and volume of roots and stones (Soil Survey Staff, 2014). Prior to the chemical analyses, we passed each field-moist sample through a 4-mm sieve. To determine $\mathrm{pH}$, we mixed the soils and water in a 1-to-1 volumetric ratio and measured the $\mathrm{pH}$ of the supernatant after 10 min using a benchtop meter (VWR sympHony Sb70p; Allen, 1989). We estimated water holding capacity by saturating each sample and allowing it to drain freely for $2 \mathrm{~h}$ then weighing, drying at $105^{\circ} \mathrm{C}$, and re-weighing each sample (Paul et al., 2001). For microbial biomass, we used a modified substrate-induced respiration method that measures rates of $\mathrm{CO}_{2}$ efflux over a 4-h incubation period using an Infra-Red Gas Analyzer (IRGA, Li-COR model Li-7000, West and Sparling, 1986; Bradford

et al., 2008). This method provides an estimate of active microbial biomass (Wardle and Ghani, 1995). We used a ball mill to grind air-dried soil samples to a fine powder and analyzed total $\mathrm{C}$ and $\mathrm{N}$ concentrations using a Costech ESC 4010 Elemental Analyzer (Costech Analytical Technologies Inc.,Valencia, CA). We calculated $\mathrm{C}$ stocks using a mass-dependent rather than depth-dependent 
approach since we expected bulk density to decrease following site preparation and the addition of trees (Gifford and Roderick, 2003; Wendt and Hauser, 2013). Linear interpolation of soil C estimates from cores collected at two depths was used to calculate $\mathrm{C}$ stocks for a standard dry soil mass. Finally, we analyzed the percent sand, silt, and clay-sized particles using the hydrometer method. For each plot, we calculated the ratio of coarse to fine soil particles for use in our analysis by dividing percent sand by the sum of percent clay and silt.

\subsection{Statistical analyses}

We used a series of linear mixed effect models (LMMs) to address our three research questions. For all analyses except soil $\mathrm{C}$ stocks, we used surface soil data $(0-8 \mathrm{~cm})$. For all LMMs, we standardized and centered continuous predictors by subtracting the mean and dividing by two standard deviations so that continuous and binary variables both had means of 0 and standard deviations of 0.5 (Gelman, 2008). We observed that the east side of the park ( $n=26)$ was located closer to adjacent forest stands and had less foot traffic than the west side ( $n=28$; Fig. 1$)$, so we included side as a random effect in all of the LMMs to account for these differences (Doroski et al., 2018). We calculated variance explained by fixed effects (marginal $R^{2}$ ) and by fixed and random effects (conditional $R^{2}$ ) using the method described by Nakagawa and Schielzeth (2013). We normalized the $95 \%$ confidence intervals of the means to account for repeated measures of the same plot (Cousineau, 2005; Morey, 2008). We considered coefficients with $P<0.05$ to be significant and coefficients with $P<0.10$ to be marginally significant. We fit all models using a Gaussian error distribution and ran analyses with the 'Ime4' package in $\mathrm{R}$ (version 3.4.2; R Core Team, 2020; Bates et al., 2015).

\subsection{1 (Q1) Long-term effects of the experimental treatments on soil conditions (2009 versus 2016)}

We used a series of LMMs to assess the impacts of the three experimental restoration treatments on $\mathrm{pH}$, microbial biomass, $\% \mathrm{C}, \% \mathrm{~N}$, water holding capacity, bulk density, and soil $\mathrm{C}$ stocks. Fixed effects included year, the three experimental treatments (i.e., presence or absence of compost, presence or absence of shrubs, and two or six planted tree species), the soil texture index (i.e., ratio of coarse to fine soil particles), and the two-way interaction between year and each of the 
treatments. For the $\mathrm{pH}$ models, we included a second order term for soil texture since we observed a non-linear, unimodal relationship. In these models, the fixed effect year compares baseline conditions from 2009 to conditions six-years post-planting in 2016 and therefore signifies the restoration effect. Interactions between year and the experimental treatments therefore indicate that the restoration effect was dependent on that particular treatment. All response variables met assumptions of normality and homoscedasticity. We initially analyzed $\mathrm{pH}$ data as hydrogen ion concentration (i.e., the inverse log of $\left.\mathrm{pH} ;\left[\mathrm{H}^{+}\right]\right)$since it is on a linear rather than logarithmic scale. However, because we needed to natural log-transform $\left[\mathrm{H}^{+}\right]$to meet model assumptions, we ultimately chose to analyze the data as $\mathrm{pH}$ since it is more readily interpreted by land managers. We report all relative changes in soil acidity as $\left[\mathrm{H}^{+}\right]$. We included plot and plot nested within side (east or west) as random effects to account for repeated measurements in the same plot in different years.

Based on model outputs, we ran a post-hoc analysis to further investigate the strong year by compost interaction observed for all soil response variables with the exception of bulk density (Appendix S1: Table S1). The post-hoc models assessed the restoration effect from 2009 to 2016 (as indicated by year) in the subset of plots with $(n=26)$ and without $(n=28)$ compost amendments. Fixed effects included year (i.e., restored data from 2016 or unrestored baseline data from 2009) and the soil texture index (i.e., ratio of coarse to fine soil particles). Again, we included a second order term for soil texture in the $\mathrm{pH}$ models. Random effects included plot and plot nested within side.

\subsection{2 (Q2) Changes in the experimental treatment effects over time (2011 to 2016)}

Using the same soil response variables described for Q1 (with the exception of soil C stocks which we did not collect in 2011), we created a series of LMMs with year (i.e., 2011 or 2016), the three experimental treatments (presence or absence of compost, presence or absence of shrubs, and two or six planted tree species), the soil texture index, and the two-way interaction between year and each of the treatments as fixed effects. For these models, the fixed effect year compares conditions one-year post-planting in 2011 to conditions six-years post-planting in 2016 and therefore signifies changes in the restoration effects over time. Again, we included plot and plot nested within side as random effects. 


\subsection{3 (Q3) Association between soil conditions and tree growth}

We created a series of LMMs using the 2016 surface soil data and tree basal area data from 2011 and 2016. For these models, we limited our analyses to the two species (Q. rubra and T. americana) present in both the two- and six-species plots since we would otherwise be unable to make cross-treatment comparisons. Over the course of the experiment, 137 Q. rubra and $95 T$. americana either died, were reported missing, or re-sprouted, and detailed field notes suggested that these instances were primarily the result of extreme herbivory or vandalism (e.g., fire, see Oldfield et al. 2015). Since our objective was to examine the potential influence of soil conditions on tree growth, we removed dead, missing, or re-sprouted individuals from our tree growth dataset since these factors (e.g., vandalism) were beyond the scope of this study. The final dataset included 299 Q. rubra and

\section{T. americana.}

We built our tree growth LMMs with 2011 DRC (hereafter referred to as "initial DRC") as a predictor variable and 2016 tree basal area as the response. This model structure accounted for the fact that trees with larger DRC measurements at the time of planting would also be expected to have larger DBH values in 2016 independent of differences in soil conditions. To select the soil variables included as predictors in the LMMs, we created a correlation matrix with all 2016 surface $(0-8 \mathrm{~cm})$ soil variables to ensure that we would not violate the assumptions of no multicollinearity (Appendix $\mathrm{S} 1$ : Fig. S1). Through this process, we selected $\left[\mathrm{H}^{+}\right], \% \mathrm{~N}$, and microbial biomass, all of which had correlation coefficients $<0.50$. Because we observed a non-linear, unimodal relationship between microbial biomass and basal area, we added a second-order microbial biomass term to improve the model fit. We used this model structure to evaluate the relationships between soil conditions and the basal area of Q. rubra and T. americana combined, as well as Q. rubra and T. americana alone, since we expected the two species to have different growth rates. Based on strong effects of the compost treatments (as opposed to the shrub and composition treatments) on soil conditions (Appendix S1: Table S1), we further investigated the impacts of compost on tree growth by creating additional LMMs (with the same model structure as the full tree growth model) using data from amended plots only $(n=26)$ and unamended plots only $(n=28)$. This approach allowed us to compare the relative 
effects of soil variables on tree growth in amended and unamended plots without violating model assumptions (e.g., multicollinearity between compost treatments and soil variables). Variance inflation factors (VIF) less than 1.7 suggested that multicollinearity was sufficiently low among these predictor variables.

\section{Results}

3.1 (Q1) Long-term effects of the experimental treatments on soil conditions (2009 versus 2016)

Overall, we found significant differences in all measured soil variables six-years post-planting relative to baseline conditions. These changes included increased mean $\% \mathrm{~N}$, microbial biomass, water holding capacity, and \%C and reduced soil $\mathrm{pH}$ and bulk density (Fig. 2; Appendix S1: Tables S1, S2). The positive effect across all 54 plots was largest for $\% \mathrm{~N}$, which increased by $54 \%$ in 2016 relative to baseline conditions, followed by microbial biomass, water holding capacity, and $\% \mathrm{C}$, which increased by $23 \%, 20 \%$, and 15\%, respectively (Fig. 2; Appendix S1: Tables S1, S2). Mean soil pH (+ SE) across the 54 plots declined from $7.36+0.07$ to $7.21+0.06$, which is equivalent to a $41 \%$ increase in soil acidity (calculated using $\left[\mathrm{H}^{+}\right]$), and mean bulk density ( $\pm \mathrm{SE}$ ) decreased from $1.37 \pm 0.06$ to 0.93 $\pm 0.02 \mathrm{~g} \mathrm{~cm}^{-3}$, which is a $32 \%$ reduction in soil compaction (Fig. 2; Appendix S1: Tables S1, S2).

The magnitude of the effects of site preparation and tree planting also varied substantially by the experimental treatments (Table 1; Appendix S1: Table S1). Most notably, we observed a strong interaction between year and the compost treatments for all soil variables except bulk density (Appendix S1: Table S1), indicating that the soil responses to site preparation and tree planting were dependent on compost addition. In contrast, we found no evidence that the shrub or composition treatments influenced how soils responded to site preparation and tree planting since interactions between year and these treatments were weak (Appendix S1: Tables S1, S2). For pH and \%C, only the compost-amended plots showed differences six-years post-restoration relative to baseline conditions (Table 1). Compost-amended plots $(n=26)$ in 2016 were two times more acidic $(7.01+$ 0.08 mean $\mathrm{pH}+\mathrm{SE})$ than unamended plots $(n=28,7.40+0.08)$, which were unchanged relative to baseline levels from 2009 (7.42 + 0.084; Table 1; Fig. 2). Likewise, mean \%C ( \pm SE) increased by $35 \%$ in compost-amended plots from $2009(5.1 \pm 0.2 \%)$ to $2016(6.9 \pm 0.3 \%)$ but was unchanged in the unamended plots (Table 1; Fig. 2). For microbial biomass, $\% \mathrm{~N}$, and water holding capacity, both 
the amended and unamended plots showed significant differences in 2016 relative to baseline conditions, but the changes were more pronounced in compost-amended plots (Table 1; Fig. 2). Mean $( \pm \mathrm{SE}) \% \mathrm{~N}$ increased by $92 \%$ in amended plots $(0.46 \pm 0.025 \%)$ but only by $21 \%$ in unamended plots (0.29 $\pm 0.014 \%$; Table 1; Fig. 2). Similarly, water holding capacity and microbial biomass increased by $24 \%$ and $32 \%$ in compost-amended plots but only by $17 \%$ and $13 \%$ in unamended plots, respectively.

We found no significant main effects of the experimental treatments on belowground $\mathrm{C}$ stocks six-years post-planting relative to baseline conditions across all 54 plots (Appendix S1: Fig. S2, Tables S1, S2). However, interpretation of the main effects is confounded by the opposing effects of the compost treatments as revealed by the significant year by compost interaction (Table 1; Appendix S1: Fig. S2, Table S1). Whereas amended plots had significantly higher soil C stocks relative to baseline conditions, unamended plots had significantly lower stocks (Table 1; Appendix S1: Fig. S2, Table S2). Mean ( \pm SE) belowground C in compost-amended plots was 16.7\% higher in $2016(5.6 \pm$ $0.29 \mathrm{~kg} \mathrm{C} \mathrm{m}^{-2}$ at $2.5 \mathrm{~kg}$ soil depth) than in 2009 (4.8 $\pm 0.18 \mathrm{~kg} \mathrm{C} \mathrm{m}^{-2}$ at $2.5 \mathrm{~kg}$ soil depth; Table 1; Appendix S1: Fig. S2, Table S2). In contrast, we observed a 10.4\% decline in mean ( \pm SE) soil C stocks in unamended plots in $2016\left(4.3 \pm 0.28 \mathrm{~kg} \mathrm{C} \mathrm{m}^{-2}\right.$ at $2.5 \mathrm{~kg}$ soil depth) relative to baseline conditions (Table 1; Appendix S1: Fig. S2, Table S2). In both instances, these changes marked a precipitous decline in soil $\mathrm{C}$ relative to peak conditions in 2010 immediately following site preparation (Appendix S1: Fig. S2).

\section{2 (Q2) Changes in the experimental treatment effects over time (2011 to 2016)}

Overall, the magnitude of the effects of site preparation, tree planting, and the experimental treatments diminished from one- to six-years post-planting (Fig. 2; see Oldfield et al., 2014 for results for 2009 through 2011). Changes in soil conditions from 2011 to 2016 ranged from positive to neutral to negative, indicating that for some variables the effects of site preparation and planting continued to increase six-years post-restoration whereas for others it plateaued or began to decline (Table 2; Fig.

2). For instance, there was a positive association between water holding capacity and year, indicating that this variable continued to increase from one- to six-years post restoration (Table 2; Fig. 2). However, we observed no changes in microbial biomass or $\% \mathrm{~N}$ from 2011 to 2016 , suggesting that 
these variables plateaued after one year (Table 2; Fig. 2). Moreover, the rise in $\% \mathrm{C}$ and reduction in bulk density observed during the first three years of this study diminished from 2011 to 2016. Percent C declined by $13 \%$ and bulk density increased by $29 \%$, indicating higher levels of soil compaction in 2016 relative to 2011 (Table 2; Fig. 2).

In some instances, compost amendments sustained altered soil conditions even when the trend from one- to six-years post-planting across all 54 plots was neutral or negative. For example, despite the overall decline in \% $\mathrm{C}$ from 2011 to 2016, compost-amended plots had constant \%C values during this timeframe, indicating that the compost treatment counteracted the decline in $\% \mathrm{C}$ observed in unamended plots (Table 2; Fig. 2). We also found significant interactions between year and compost for $\mathrm{pH}$, water holding capacity, and bulk density. Although soil acidity decreased by $55 \%$ in amended plots between $2011(6.66+0.09$, mean $\mathrm{pH}+\mathrm{SE})$ and $2016(7.01+0.08)$, the compost treatment still sustained significantly higher soil acidity (i.e., lower $\mathrm{pH}$ values) than unamended plots in 2016 (Table 1, Fig. 2; Appendix S1: Table S2). The increase in mean water holding capacity from 2011 to 2016 was higher in unamended plots than in compost-amended plots, but amended plots still retained higher overall water holding capacities in 2016 (Table 1, Fig. 2; Appendix S1: Fig. S2). For bulk density, the positive effect of year was more pronounced in amended plots than in unamended plots, but this trend did not result in significant differences in bulk density between the compost treatments in 2016 (Tables 1, 2, Fig. 2; Appendix S1: Table S2). There were no significant interactions between year and the shrub or composition treatments for any of the measured soil variables (Table 2).

\section{3 (Q3) Association between soil conditions and tree growth}

Mean basal area for planted trees in 2016 was $0.116 \mathrm{~m}^{2} \mathrm{ha}^{-1}( \pm \mathrm{SE} 0.04)$, but this value ranged from $0.002 \mathrm{~m}^{2} \mathrm{ha}^{-1}$ to $0.513 \mathrm{~m}^{2} \mathrm{ha}^{-1}$ among the plots. Tilia americana had higher mean basal area $(0.512 \pm 0.006)$ than Quercus rubra $(0.063 \pm 0.003)$. When T. americana and Q. rubra were evaluated together, soil $\% \mathrm{~N}$ had a significant positive association with basal area, and microbial biomass had a marginally significant negative association but only once it exceeded $\sim 1.5 \mu \mathrm{g} \mathrm{C}-\mathrm{CO}_{2} \mathrm{~g}$ soil $^{-1} \mathrm{~h}^{-1}$ (Appendix S1: Table S3). These associations were, however, driven entirely by $T$. americana's response to soil characteristics. When analyzed separately, $\% \mathrm{~N}$ continued to have a significant positive association with $T$. americana basal area, and microbial biomass had a marginally 
negative association. However, none of the three tested soil variables were significant predictors of $Q$. rubra basal area (Appendix S1: Table S3). When plots amended with compost and unamended plots were analyzed separately, none of the soil variables tested were significant predictors of basal area in amended plots (Table 3; Appendix S1: Fig. S3). In contrast, unamended plots had significantly higher basal area as $\% \mathrm{~N}$ increased and significantly lower basal area as microbial biomass exceeded $1.5 \mu \mathrm{g}$ C- $\mathrm{CO}_{2}$ g soil $^{-1} \mathrm{~h}^{-1}$ (Table 3; Appendix S1: Fig. S3).

\section{Discussion}

As investments in urban tree planting initiatives grow, so too should our understanding of best practices for the implementation and management of these projects. Urban soils, particularly those of anthropogenic origin, are an understudied but integral aspect of afforestation that affect the capacity of a site to support a range of management goals (Pavao-Zuckerman, 2008; Oldfield et al., 2014).

Globally, soil health initiatives are touted as a means to mitigate climate change through belowground $\mathrm{C}$ sequestration while also enhancing ecological processes, such as microbial activity and nutrient cycling (Bradford et al. 2019; Vermeulen et al., 2019). Although soil health is context-dependent, certain properties and processes are known to support common management objectives and can therefore be used as system-specific indicators of restoration success (Heneghan et al., 2008; PavaoZuckerman, 2008; Bünemann et al., 2018). Soil pH governs chemical and biological processes that affect plant nutrient uptake; water holding capacity and bulk density reflect soil porosity, aeration, and moisture availability required for root growth, water infiltration, and drought resistance; $\mathrm{C}$ and $\mathrm{N}$ concentrations are indicative of the amount and composition of organic matter and thus potential nutrient availability; and microbial biomass controls the cycling and transformation of nutrients, thereby making them available for plant uptake through decomposition. Each of these variables showed significant improvements six-years post-restoration relative to baseline conditions, and the response was largest in the compost-amended plots. These soil health improvements also had positive impacts on urban forest management objectives, including increasing variables indicative of stormwater mitigation, belowground $\mathrm{C}$ storage, and native tree growth.

Urban soils often have elevated $\mathrm{pH}$ levels owing to chemical inputs from run-off and weathering of impervious surfaces, such as concrete (Craul, 1985; Jim, 1998a). Within forested

This article is protected by copyright. All rights reserved 
natural areas in New York City, for instance, $\mathrm{pH}$ increases across gradients of soil and canopy disturbance (Pregitzer et al., 2016), and these changes are often associated with higher invasive plant cover (Ward et al., 2020). Non-urban temperate deciduous forests, on the other hand, commonly have acidic soils (Osman, 2013), and the optimal pH values for the planted tree species at the experimental site range from slightly acidic (4.5-6.8 for Q. alba and 5.0-6.6 for C. laciniosa) to moderately alkaline ( 4.8-7.3 for C. glabra, 4.3-7.3 for Q. rubra, 4.0-7.5 for P. serotina, 4.5-7.5 for T. americana, and 6.0-7.8 for C. occidentalis; Krajicek and Williams, 1990; Marquis, 1990; Osman, 2013; USDA PLANTS, 2020; Rogers, 1990; Sander, 1990; Schlesinger, 1990; Smalley, 1990). Therefore, the reduction in mean soil $\mathrm{pH}$ in the compost-amended plots (7.0) relative to baseline conditions (7.3) indicates that $\mathrm{pH}$ may be approaching an optimal value range for all planted tree species. However, the soils in these plots were still substantially less acidic than mature forests within New York City (mean pH of 5.21; Ward et al., 2020), and the rise in pH from 2011 to 2016 suggests that the effects of the compost amendments on $\mathrm{pH}$ may be diminishing. Yet the planted trees are young ( $\leq 11$ years old), and over time we expect maturing trees to exert greater effects on soil acidity through increasing quantities of decomposing organic inputs into the soil.

Improving hydrology through natural solutions is a critical goal for urban land management since chemical-laden runoff is a major environmental pollutant (Booth and Jackson, 1997; Kuehler et al., 2017; Phillips et al., 2019). Urban areas are often characterized by expansive impervious surfaces and compacted soils (Effland and Pouyat, 1997), which limits their capacity to retain large volumes of water following storm events. We observed a significant decrease in bulk density—signifying reduced soil compaction - and an increase in water holding capacity, indicating that the physical soil environment is better able to support key ecosystem services through improved porosity, aeration, and moisture availability. Indeed, mean bulk density values in $2016\left(0.93 \mathrm{~g} \mathrm{~cm}^{-3}\right)$ are within the range of values for uncultivated forests and grasslands ( 0.8 to $1.2 \mathrm{~g} \mathrm{~cm}^{-3}$; Brady and Weil, 2008) and similar to baseline conditions of forested reference sites within the park $\left(0.84 \mathrm{~g} \mathrm{~cm}^{-3}\right.$; Oldfield et al., 2014).

Moreover, water holding capacity was the only variable that continued to improve from one- to sixyears post-planting, and this is likely the result of increasing root growth of the planted trees, which can increase water infiltration and retention. Although peak water holding capacity values were observed in 2010 following site preparation and compost applications (Oldfield et al., 2014), 
improvements from 2011 to 2016 suggest that the benefits of afforestation-rather than site preparation - are beginning to accrue in amended and unamended plots alike.

We found that compost amendments were key to sustaining long-term increases in belowground $\mathrm{C}$ storage as a result of urban afforestation. In the absence of compost, the effects of site preparation and planting on $\mathrm{C}$ concentrations and stocks were neutral and negative, respectively, despite the surface application of mulch to all plots. These findings are consistent with previous research that has found that afforestation can initially decrease soil C (Berthrong et al., 2009; Laganière et al., 2010; Wellock et al., 2011; Berthrong et al., 2012; Li et al., 2012), particularly when planting is associated with high levels of disturbance during site preparation (Laganière et al., 2010) or when initial C concentrations are high (Hong et al., 2020). However, we found that C concentrations and stocks both increased with the addition of compost. In heavily-used and/or degraded urban sites, soil compaction can limit tree growth, necessitating tilling practices to reduce bulk density (Jim, 1993; Jim, 1998b). However, tillage also depletes soil C by disrupting aggregate formation, thereby exposing organic matter to levels of decomposition that exceed plant $\mathrm{C}$ inputs (Six et al., 2000; Haddaway et al., 2017). Yet our results suggest that compost amendments can offset the negative impacts of tilling on soil $\mathrm{C}$ in urban afforestation projects over longer timeframes. Other studies have similarly found that organic amendments are required to build $\mathrm{C}$ stocks in urban soil remediation projects, particularly when initial organic matter concentrations are low (Beesley, 2012; Chen et al., 2013). Rebuilding soil $\mathrm{C}$ in intensively-managed systems has a multitude of co-benefits beyond climate mitigation (Bradford et al., 2019; Vermeulen et al., 2019). For instance, trends in soil microbial biomass, $\mathrm{C}$ stocks, and $\mathrm{C}$ and $\mathrm{N}$ concentrations observed in this study signify a build-up of organic matter as well as the potential mineralization of nutrients through microbial activity, which improves soil fertility. Thus, our results suggest that, when coupled together, compost amendments and tilling can have long-term positive impacts on soil physical, chemical, and biological properties and processes required to support tree growth and to sequester and store belowground $\mathrm{C}$.

Although we observed long-lasting impacts of site preparation and compost on soil conditions, the linear trends in soil $\mathrm{pH}$ (analyzed as $\left[\mathrm{H}^{+}\right]$), bulk density, and microbial biomass observed during the first three years of this study (Oldfield et al., 2014) tapered or declined from 2011 to 2016. Extrapolation of initial trends can therefore lead to poor projections compared to observed values, 
emphasizing the importance of longer-term studies for quantifying restoration outcomes. Moreover, it remains unclear whether the positive effects of restoration continue to be driven by initial site preparation and compost amendments (Oldfield et al. 2014), or whether they are increasingly the result of tree growth, canopy closure, and understory plant recruitment. Over time, we would expect the growth of planted trees to increase in their effects on soil conditions. For example, planted trees can reduce bulk density and increase water holding capacity through root expansion (Vidal-Beaudet et al., 2018) as well as increase soil C stocks as leaf litter and fine root inputs are incorporated into the soil (Six et al., 2002). Although we were unable to directly test these relationships with an unplanted (i.e., no trees) experimental treatment since the project was a collaboration with city agencies in a high visibility park with defined public-private tree-planting goals, we advocate for future work that specifically examines the role that planted trees play in improving soil conditions relative to other site treatments.

Because the primary goal of urban afforestation projects is to establish closed-canopy, nativedominated forests (Gobster, 2010), we also evaluated the effects of improved soil conditions on planted tree growth. Although we did not detect any changes in tree growth in response to soils in plots that were amended with compost, tree growth increased significantly with increases in $\% \mathrm{~N}$ in unamended plots. This finding suggests that compost amendments shifted soil conditions so that $\mathrm{N}$ was no longer limiting tree growth. Indeed, this one-time compost application appeared sufficient to transition the soils at our study site to a threshold that could support tree growth (in $2016 \% \mathrm{~N}$ ranged from $0.17 \%$ to $0.45 \%$ in unamended plots versus $0.26 \%$ to $0.66 \%$ in amended plots). Compost applications in urban settings can range in intensity from low-cost surface spreading to more timeand cost-intensive methods that incorporate compost into the soil to a depth of up to $60 \mathrm{~cm}$ (Kranz et al. 2020). In our study, we incorporated compost to $15 \mathrm{~cm}$ and found that increases in tree growth diminished as soil $\mathrm{N}$ approached $\sim 0.4 \%$, suggesting that more time- and cost-intensive practices may not yield the same incremental benefits. Furthermore, responses to soil conditions were speciesdependent. Tilia americana demonstrated more vigorous growth as a result of improved soil conditions whereas Q. rubra did not. These species-specific responses are worth considering given that compost applications can be expensive (EPA, 2020). Moreover, Doroski et al. (2018) found that regeneration of non-native woody plants was significantly higher in compost-amended plots at the 
experimental site, which could jeopardize goals to establish native-dominated forests in urban areas (Pregitzer et al., In press). As such, we suggest that land managers consider potential trade-offs between compost applications, planted tree composition, and recruitment from non-native and invasive species.

Afforestation of degraded urban landscapes can involve obstacles different from those found in non-urban settings, such as remediating disturbed soil conditions of anthropogenic origin (Effland and Pouyat, 1997; Pavao-Zuckerman, 2008). Yet as the proportion of the global population residing in cities continues to grow, investments in restoration projects that support and improve ecosystem services in urban greenspaces will become increasingly important (Pataki et al., 2011; Elmqvist et al., 2015). We found marked improvements in soil health conditions six-years post-restoration relative to baseline conditions. Although indicators of soil quality are highly context-dependent (Bünemann et al., 2018), our results support the future implementation of soil-focused site treatments in our study region and can help inform expectations for the duration and effects of different restoration practices. In particular, the addition of compost had substantial, long-lasting effects and increased the capacity of the site to support other management objectives, such as belowground $\mathrm{C}$ storage and the growth of planted trees. These planted trees will, in turn, hopefully support a multitude of additional ecosystem services, such as aboveground $\mathrm{C}$ storage. Thus, our results suggest that compost applications along with targeted plant selection may be critical to realizing the potential of urban afforestation projects as nature-based solutions in moist, temperate systems.

\section{Acknowledgments}

We thank AECOM, Inc. for planning, coordinating, and designing the experiment, and the New York

City Department of Parks and Recreation and the New York City Urban Field Station for constructing the study site and facilitating the research. Thanks also to Julia Monk, Annie Stoeth, Megan Carr, and Steve Wood for assistance with lab analyses, Dan Kane, the Yale Soil Science class of 2010, Dan Maynard, Noah Sokol, Novem Auyeung, Clara Pregitzer, Tom Crowther, Nancy Sonti, Mike Strickland, and Yoshiki Harada for assistance with fieldwork, and Max Piana for feedback on the manuscript. Soil total C and $\mathrm{N}$ was determined in the Yale Analytical and Stable Isotope Center. Authors' contributions: EBW and DAD contributed equally to this work. DAD and EBW conducted 
the 2016 laboratory measurements, carried out statistical analyses, interpreted the results, and wrote the original manuscript, with contributions from all authors. MAB, AJF, EEO and RAH designed the study, and all authors contributed to field and laboratory measurements.

\section{Supporting Information}

Additional supporting information may be found online at: [link to be added in production]

\section{Data Availability}

Data (Doroski and Ward 2021) are available in the Dryad Digital Repository: https://doi.org/10.5061/dryad.qnk98sffm

\section{References}

Allen, S.E. 1989. Chemical Analysis of Ecological Materials. Blackwell Scientific, Oxford.

Bates, D., M. Mächler, B. M. Bolker, and S. C. Walker. 2015. Fitting Linear Mixed-Effects Models Using lme4. Journal of Statistical Software 67: 1-48. https://doi.org/10.18637/jss.v067.i01 Beesley, L. 2012. Carbon storage and fluxes in existing and newly created urban soils. Journal of Environmental Management 104: 158-165. https://doi.org/10.1016/j.jenvman.2012.03.024

Berthrong, S. T., E. G. Jobbágy, and R. B. Jackson. 2009. A global meta-analysis of soil exchangeable cations, $\mathrm{pH}$, carbon, and nitrogen with afforestation. Ecological Applications 19:2228-2241.

Berthrong, S. T., G. Piñeiro, E. G. Jobbágy, and R. B. Jackson. 2012. Soil C and N changes with afforestation of grasslands across gradients of precipitation and plantation age. Ecological Applications 22:76-86.

Booth, D.B. and C. R. Jackson. 1997. Urbanization of Aquatic Systems: Degradation Thresholds, Stormwater Detection, and the Limits of Mitigation. Journal of the American Water Resources Association 33: 1077-1090. https://doi.org/10.1111/j.1752-1688.1997.tb04126.x

Bradford, M.A., C. J. Carey, L. Atwood, D. Bossio, E. P. Fenichel, S. Gennet, J. Fargione, J. R. B. Fisher, E. Fuller, D. A. Kane, J. Lehmann, E. E. Oldfield, E. M. Ordway, J. Rudek, J. 
Sanderman, and S A. Wood. 2019. Soil carbon science for policy and practice. Nature Sustainability 2: 1070-1072. https://doi.org/10.1038/s41893-019-0431-y

Bradford, M.A., C. A. Davies, S. D. Frey, T. R. Maddox, J. M. Melillo, J. E. Mohan, J. D. Reynolds, K. K. Treseder, M. D. 2008. Thermal adaptation of soil microbial respiration to elevated temperature. Ecology Letters 11: 1316-1327. https://doi.org/10.1111/j.14610248.2008.01251.x

Brady, N.C. and R. R. Weil. 2008. The Nature and Properties of Soils. 14th edition. Pearson, London, UK.

Brunner, I., C. Herzog, M. A. Dawes, M. Arend, and C. Sperisen. 2015. How tree roots respond to drought. Frontiers in Plant Science 6: 547. https://doi.org/10.3389/fpls.2015.00547

Bünemann, E.K., G. Bongiorno, Z. Bai, R. E. Creamer, G. De Deyn, R. de Goede, L. Fleskens, V. Geissen, T. W. Kuyper, P. Mäder, M. Pulleman, W. Sukkel, J. W. van Groenigen, and L. Brussaard. 2018. Soil quality - A critical review. Soil Biology and Biochemistry 120: 105125. https://doi.org/10.1016/j.soilbio.2018.01.030

Cao, S., L. Chen, C. Xu, and Z. Liu. 2007. Impact of three soil types on afforestation in China's Loess Plateau: Growth and survival of six tree species and their effects on soil properties. Landscape and Urban Planning 83(2): 208-217. https://doi.org/10.1016/j.landurbplan.2007.04.006

Capra, G. F., A. Ganga, E. Grilli, S. Vacca, and A. Buondonno. 2015. A review on anthropogenic soils from a worldwide perspective. Journal of Soils and Sediments 15(7): 1602-1618. https://doi.org/10.1007/s11368-015-1110-x

Chen, Y., S. D. Day, A. F. Wick, B. D. Strahm, P. E. Wiseman, and W. L. Daniels. 2013. Changes in soil carbon pools and microbial biomass from urban land development and subsequent postdevelopment soil rehabilitation. Soil Biology and Biochemistry 66:38 44. https://doi.org/10.1016/j.soilbio.2013.06.022

Chojnacky, D. C. and P. Rogers. 1999. Converting Tree Diameter Measured at Root Collar to Diameter at Breast Height. Western Journal of Applied Forestry 14(1): 14-16. https://doi.org/10.1093/wjaf/14.1.14

Cogger, C.G. 2005. Potential compost benefits for restoration of soils disturbed by urban development. Compost Science and Utilization 13: 243-251.

This article is protected by copyright. All rights reserved 
Cousineau, D. (2005). Confidence intervals in within-subject designs: A simpler solution to Loftus and Masson's method. Tutorial in Quantitative Methods for Psychology 1: 42-45.

Craul, P.J. 1985. A description of urban soils and their desired characteristics. Journal of Arboriculture 11: 330-339.

Crow, T. R. 1990. Tilia americana L.: American basswood. Silvics of North America 2: 784-791.

Doelman, J. C., E. Stehfest, D. P. van Vuuren, A. Tabeau, A. F. Hof, M. C. Braakhekke, D. E. H. J. Gernaat, M. van den Berg, W.-J. van Zeist, V. Daioglou, H. van Meijl, and P. L. Lucas. 2020. Afforestation for climate change mitigation: Potentials, risks and trade-offs. Global Change Biology 26:1576-1591.

Doroski, D. A., A. J. Felson, M. A. Bradford, M. P. Ashton, E. E. Oldfield, R. A. Hallett, and S. E. Kuebbing. 2018. Factors driving natural regeneration beneath a planted urban forest. Urban Forestry and Urban Greening 29, 238-247. https://doi.org/10.1016/j.ufug.2017.11.019

Doroski, D., and E. Ward. 2021. Positive long-term impacts of restoration on soils in an experimental urban forest. Dryad, data set. https://doi.org/10.5061/dryad.qnk98sffm

Effland, W.R. and R. V. Pouyat. 1997. The genesis, classification, and mapping of soils in urban areas. Urban Ecosystems 1: 217-228. https://doi.org/10.1023/A:1018535813797

Elmqvist, T., H. Setälä, S. Handel, S. van der Ploeg, J. Aronson, J. Blignaut, E. Gómez-Baggethun, D. Nowak, J. Kronenberg, and R. de Groot. 2015. Benefits of restoring ecosystem services in urban areas. Current Opinion in Environmental Sustainability 14: 101-108. https://doi.org/10.1016/j.cosust.2015.05.001

EPA. 2020. Current Compost Usage by State DOTs. Available from: https://www.epa.gov/sites/production/files/2015-11/documents/highwy3a.pdf. Accessed November 13, 2020.

Felson, A.J., M.A. Bradford, and E.E. Oldfield. 2013. Involving ecologists in shaping large-scale green infrastructure projects. Bioscience. 63 (11): cover and 881-890.

Gelman, A. 2008. Scaling regression inputs by dividing by two standard deviations. Statistics in Medicine 27: 2865-2873. https://doi.org/10.1002/sim.3107

This article is protected by copyright. All rights reserved 
Gifford, R.M. and M. L. Roderick. 2003. Soil carbon stocks and bulk density: spatial or cumulative mass coordinates as a basis of expression? Global Change Biology 9: 1507-1514. https://doi.org/10.1046/j.1365-2486.2003.00677.x

Giménez, J. E., M. I. Salerno, and M. A. Hurtado. 2002. Rehabilitation of desurfaced soils by afforestation in La Plata County, Argentina. Land Degradation and Development 13(1): 6977. https://doi.org/10.1002/ldr.478

Gobster, P. H. 2010. Models for urban forest restoration: Human and environmental values. In:

Stanturf, J. ed. Proceedings of the IUFRO conference on forest landscape restoration; 2007

May 14-19; Seoul, Korea. Seoul, Korea: Korea Forest Research Institute: 10-13.

Gomez-Aparicio, L., J. M. Gomez, R. Zamora, and J. L. Boettinger. 2005, Canopy vs. soil effects of shrubs facilitating tree seedlings in Mediterranean montane ecosystems. Journalof Vegetation Science 16: 191-198.

Griscom, B.W., J. Adams, P. W. Ellis, R. A. Houghton, G. Lomax, D. A. Miteva, W. H. Schlesinger, D. Shoch, J. V. Siikamäki, P. Smith, P. Woodbury, C. Zganjar, A. Blackman, J. Campari, R. T. Conant, C. Delgado, P. Elias, T. Gopalakrishna, M. R. Hamsik, M. Herrero, J. Kiesecker, E. Landis, L. Laestadius, S. M. Leavitt, S. Minnemeyer, S. Polasky, P. Potapov, F. E. Putz, J. Sanderman, M. Silvius, E. Wollenberg, and J. Fargione. 2017. Natural climate solutions. Proceedings of the National Academy of Sciences 114: 11645-11650. https://doi.org/10.1073/pnas.1710465114

Guerrini, I. A., C. G. G. Croce, O. C. Bueno, C. P. R. P. Jacon, T. A. R. Nogueira, D. M. Fernandes, A. Ganga, and G. F. Capra. 2017. Composted sewage sludge and steel mill slag as potential amendments for urban soils involved in afforestation programs. Urban Forestry and Urban Greening 22: 93-104. https://doi.org/10.1016/j.ufug.2017.01.015

Güneralp, B. and K. C. Seto. 2013. Futures of global urban expansion: uncertainties and implications for biodiversity conservation. Environmental Research Letters 8: 014025. https://doi.org/10.1088/1748-9326/8/1/014025

Haddaway, N.R., K. Hedlund, L. E. Jackson, T. Kätterer, E. Lugato, I. K. Thomsen, H. B. Jørgensen, and P. E. Isberg. 2017. How does tillage intensity affect soil organic carbon? A systematic review. Environmental Evidence 6: 30. https://doi.org/10.1186/s13750-017-0108-9

This article is protected by copyright. All rights reserved 
Hawver, G. A. and N. L. Bassuk. 2007. Soils: The key to successful establishment of urban vegetation. Pages 165-182 in J. E. Kuser, editor. Urban and Community Forestry in the Northeast. Springer, New York, NY, USA.

Heneghan, L., S. P. Miller, S. Baer, M. A. Callaham, J. Montgomery, M. Pavao-Zuckerman, C. C. Rhoades, and S. Richardson. 2008. Integrating Soil Ecological Knowledge into Restoration Management. Restoration Ecology 16, 608-617. https://doi.org/10.1111/j.1526100X.2008.00477.x

Hong, S., G. Yin, S. Piao, R. Dybzinski, N. Cong, X. Li, K. Wang, J. Peñuelas, H. Zeng, and A. Chen. 2020. Divergent responses of soil organic carbon to afforestation. Nature Sustainability 3:694700.

IPBES. 2019. Summary for policymakers of the global assessment report on biodiversity and ecosystem services of the Intergovernmental Science-Policy Platform on Biodiversity and Ecosystem Services. S. Díaz, J. Settele, E. S. Brondízio, H. T. Ngo, M. Guèze, J. Agard, A. Arneth, P. Balvanera, K. A. Brauman, S. H. M. Butchart, K. M. A. Chan, L. A. Garibaldi, K. Ichii, J. Liu, S. M. Subramanian, G. F. Midgley, P. Miloslavich, Z. Molnár, D. Obura, A. Pfaff, S. Polasky, A. Purvis, J. Razzaque, B. Reyers, R. Roy Chowdhury, Y. J. Shin, I. J. Visseren-Hamakers, K. J. Willis, and C. N. Zayas, editors. IPBES secretariat, Bonn, Germany.

Jim, C. Y. 1993. Soil compaction as a constraint to tree growth in tropical \& subtropical urban habitats. Environmental Conservation 20(1): 35-49.

Jim, C.Y. 1998a. Physical and chemical properties of a Hong Kong roadside soil in relation to urban tree growth. Urban Ecosystems 2: 171-181. https://doi.org/10.1023/A:1009585700191

Jim, C. Y. 1998b. Urban soil characteristics and limitations for landscape planting in Hong Kong. Landscape and Urban Planning 40(4): 235-249. https://doi.org/10.1016/s01692046(97)00117-5

Krajicek, J.E. and R.D. Williams. 1990. Celtis occidentalis L. Hackberry. Silvics of North America 2: 262-265.

Kranz, C. N., R. A. McLaughlin, A. Johnson, G. Miller, J. L. Miller. 2020. The effects of compost incorporation on soil physical properties in urban soils - A concise review. Journal of Environmental Management 261: 110209.

This article is protected by copyright. All rights reserved 
Kuebbing, S. E., A. P. Reimer, S. A. Rosenthal, G. Feinberg, A. Leiserowitz, J. A. Lau, and M. A. Bradford. 2018. Long-term research in ecology and evolution: a survey of challenges and opportunities. Ecological Monographs 88(2): 245-258.

Kuehler, E., J. Hathaway, and A. Tirpak. 2017. Quantifying the benefits of urban forest systems as a component of the green infrastructure stormwater treatment network. Ecohydrology 10: 1813. https://doi.org/10.1002/eco.1813

Laganière, J., D. A. Angers, and D. Paré. 2010. Carbon accumulation in agricultural soils after afforestation: A meta-analysis. Global Change Biology 16(1): 439-453. https://doi.org/10.1111/j.1365-2486.2009.01930.x

Layman, R. M., S. D. Day, D. K. Mitchell, Y. Chen, J. R. Harris, and W. L. Daniels. 2016. Below ground matters: Urban soil rehabilitation increases tree canopy and speeds establishment. Urban Forestry and Urban Greening, 16: 25-35. https://doi.org/10.1016/j.ufug.2016.01.004

Layman, R. M. 2010. Rehabilitation of Severely Compacted Urban Soil to Improve Tree Establishment and Growth. Thesis. Virginia Polytechnic Institute and State University, Blacksburg, VA, USA. https://vtechworks.lib.vt.edu/handle/10919/76910

Li, D., S. Niu, and Y. Luo. 2012. Global patterns of the dynamics of soil carbon and nitrogen stocks following afforestation: a meta-analysis. New Phytologist 195:172-181.

MacKay, D. B., P. M. Wehi, and B. D. Clarkson. 2011. Evaluating restoration success in urban forest plantings in Hamilton, New Zealand. Urban Habitats 6(1).

Magarik, Y. A. S., L. A. Roman, and J. G. Henning. 2020. How should we measure the DBH of multi-stemmed urban trees? Urban Forestry and Urban Greening 47: 126481. https://doi.org/10.1016/j.ufug.2019.126481

Marquis, D.A. 1990. Prunus serotina Ehrh. Black Cherry. Silvics of North America 2: 594-604.

McKinney, M. L. 2002. Urbanization, biodiversity, and conservation: The impacts of urbanization on native species are poorly studied, but educating a highly urbanized human population about these impacts can greatly improve species conservation in all ecosystems. BioScience 52(10): 883-890. https://doi.org/10.1641/0006-3568(2002)052[0883:UBAC]2.0.CO;2

This article is protected by copyright. All rights reserved 
McPhearson, P. T. 2011. Toward a sustainable New York City: Greening through urban forest restoration. Pages In 181-203 in M. I. Slavin, editor. Sustainability in America's Cities. Springer, New York, NY, USA.

Morel, J. L., C. Chenu, and K. Lorenz. 2015. Ecosystem services provided by soils of urban, industrial, traffic, mining, and military areas (SUITMAs). Journal of Soils and Sediments 15(8): 1659-1666. https://doi.org/10.1007/s11368-014-0926-0

Morey, R.D. 2008. Confidence intervals from normalized data: A correction to Cousineau (2005). Tutorial in Quantitative Methods for Psychology 4: 61-64.

Nave, L. E., C. W. Swanston, U. Mishra, and K. J. Nadelhoffer. 2013. Afforestation effects on soil carbon storage in the United States: A synthesis. Soil Science Society of America Journal 77(3): 1035-1047. https://doi.org/10.2136/sssaj2012.0236

Nakagawa, S. and H. Schielzeth. 2013. A general and simple method for obtaining $\mathrm{R}^{2}$ from generalized linear mixed-effects models. Methods in Ecology and Evolution 4: 133-142. https://doi.org/10.1111/j.2041-210x.2012.00261.x

Nowak, D. J. and D. E. Crane. 2002. Carbon storage and sequestration by urban trees in the USA. Environmental Pollution 116(3): 381-389. https://doi.org/10.1016/S0269-7491(01)00214-7

Oldfield, E. E., A. J. Felson, D. S. N. Auyeung, T. W. Crowther, N. F. Sonti, Y. Harada, D. S. Maynard, N. W. Sokol, M. S. Ashton, R. J. Warren, R. A. Hallett, and M. A. Bradford. 2015. Growing the urban forest: Tree performance in response to biotic and abiotic land management. Restoration Ecology 23(5): 707-718. https://doi.org/10.1111/rec.12230

Oldfield, E. E., A. J. Felson, S. A. Wood, R. A. Hallett, M. S. Strickland, and M. A. Bradford. 2014. Positive effects of afforestation efforts on the health of urban soils. Forest Ecology and Management 313: 266-273. https://doi.org/10.1016/j.foreco.2013.11.027

Osman, K.T. 2013. Forest soils: Properties and Management. Springer International Publishing, Cham, Switzerland.

Pataki, D. E., M. M. Carreiro, J. Cherrier, N. E. Grulke, V. Jennings, S. Pincetl, R. V. Pouyat, T. H. Whitlow, and W. C. Zipperer. 2011. Coupling biogeochemical cycles in urban environments: Ecosystem services, green solutions, and misconceptions. Frontiers in Ecology and the Environment 9(1): 27-36. https://doi.org/doi:10.1890/090220

This article is protected by copyright. All rights reserved 
Paul, E.A., S. J. Morris, and S. Böhm. 2001. The determination of soil C pool sizes and turnover rates: biophysical fractionation and tracers. Pages 193-205 in J. M. Kimble, R. F. Follett, and B. A. Stewart, editors. Assessment methods for soil carbon. CRC Press LLC, Boca Raton, FL, USA.

Pavao-Zuckerman, M.A. 2008. The nature of urban soils and their role in ecological restoration in cities. Restoration Ecology 16: 642-649. https://doi.org/10.1111/j.1526-100X.2008.00486.x

Phillips, T.H., M. E. Baker, K. Lautar, I. Yesilonis, and M. A. Pavao-Zuckerman. 2019. The capacity of urban forest patches to infiltrate stormwater is influenced by soil physical properties and soil moisture. Journal of Environmental Management 246: 11-18. https://doi.org/10.1016/j.jenvman.2019.05.127

Pincetl, S., T. Gillespie, D. E. Pataki, S. Saatchi, and J. D. Saphores. 2013. Urban tree planting programs, function or fashion? Los Angeles and urban tree planting campaigns. GeoJournal 78(3): 475-493. https://doi.org/10.1007/s10708-012-9446-x

Pouyat, R., P. Groffman, I. Yesilonis, and L. Hernandez. 2002. Soil carbon pools and fluxes in urban ecosystems. Environmental Pollution 116: S107-S118. https://doi.org/10.1016/s02697491(01)00263-9

Pregitzer, C.C., S. Charlop-Powers, and M.A. Bradford. In press. Natural area forests in US cities: opportunities and challenges. Journal of Forestry.

Pregitzer, C.C., N. F. Sonti, and R. A. Hallett. 2016. Variability in urban soils influences the health and growth of native tree seedlings. Ecological Restoration 34: 106-116.

R Core Development Team. 2020. R: A language and environment for statistical computing. $R$ Foundation for Statistical Computing, Vienna, Austria.

Rogers, R. 1990 Quercus alba L. White Oak. Silvics of North America 2: 605-613.

Sander, I. L. 1990. Quercus rubra L. Northern red oak. Silvics of North America 2: 727-733.

Schlesinger, R.C. 1990. Carya laciniosa (Michx. F.) Loud. Shellbark Hickory. Silvics of North America 2: 211-214.

Schwendenmann, L., and N. D. Mitchell. 2014. Carbon accumulation by native trees and soils in an urban park, Auckland. New Zealand Journal of Ecology 38(2): 213-220.

This article is protected by copyright. All rights reserved 
Seto, K. C., B. Güneralp, and L. R. Hutyra. 2012. Global forecasts of urban expansion to 2030 and direct impacts on biodiversity and carbon pools. Proceedings of the National Academy of Sciences 109(40): 16083-16088. https://doi.org/10.1073/pnas.1211658109

Shi, J. and L. Cui. 2010. Soil carbon change and its affecting factors following afforestation in China. Landscape and Urban Planning 98(2): 75-85. https://doi.org/10.1016/j.landurbplan.2010.07.011

Six, J., P. Callewaert, S. Lenders, S. D. Gryze, S. J. Morris, E. G. Gregorich, E. A. Paul, and K. Paustian. 2002. Measuring and Understanding Carbon Storage in Afforested Soils by Physical Fractionation. Soil Science Society of America Journal 66(6): 1981-1987. https://doi.org/10.2136/sssaj2002.1981

Six, J., E. T. Elliott, and K. Paustian. 2000. Soil macroaggregate turnover and microaggregate formation: a mechanism for $\mathrm{C}$ sequestration under no-tillage agriculture. Soil Biology and Biochemistry 32:2099-2103.

Smalley, G.W. 1990. Carya glabra (Mill.) Sweet Pignut hickory. Silvics of North America 2: 198204.

Soil Survey Staff. 2014. Soil Survey Field and Laboratory Methods Manual. Soil Survey Investigations Report No. 51, Version 2.0. R. Burt and Soil Survey Staff (ed.). U.S. Department of Agriculture, Natural Resources Conservation Service.

Tyrväinen, L., S. Pauleit, K. Seeland, and S. de Vries. 2005. Benefits and Uses of Urban Forests and Trees. Pages 81-114 in C. Konijnendijk, K. Nilsson, T. Randrup, and J. Schipperijn, editors. Urban Forests and Trees: A Reference Book. Springer, Berlin, Heidelberg, UK.

Vermeulen, S., D. Bossio, J. Lehmann, P. Luu, K. Paustian, C. Webb, F. Augé, I. Bacudo, T. Baedeker, T. Havemann, C. Jones, R. King, M. Reddy, I. Sunga, M. Von Unger, and M. Warnken. 2019. A global agenda for collective action on soil carbon. Nature Sustainability 2: 2-4. https://doi.org/10.1038/s41893-018-0212-z

Vidal-Beaudet, L., G. Galopin, and C. Grosbellet. 2018. Effect of organic amendment for the construction of favourable urban soils for tree growth. European Journal of Horticultural Science 83: 173-186.

This article is protected by copyright. All rights reserved 
Wang, J., H. Liu, X. Wu, C. Li, and X. Wang. 2017. Effects of different types of mulches and legumes for the restoration of urban abandoned land in semi-arid northern China. Ecological Engineering 102: 55-63. https://doi.org/10.1016/j.ecoleng.2017.02.001

Ward, E.B., C. C. Pregitzer, S. E. Kuebbing, M. A. Bradford. 2020. Invasive lianas are drivers of and passengers to altered soil nutrient availability in urban forests. Biological Invasions 22: 935955. https://doi.org/10.1007/s10530-019-02134-2

Wardle, D.A. and A. Ghani. 1995. A critique of the microbial metabolic quotient (qCO2) as a bioindicator of disturbance and ecosystem development. Soil Biology and Biochemistry 27: 1601-1610. https://doi.org/10.1016/0038-0717(95)00093-T

Wellock, M. L., C. M. LaPerle, and G. Kiely. 2011. What is the impact of afforestation on the carbon stocks of Irish mineral soils? Forest Ecology and Management 262:1589-1596.

Wendt, J.W. and S. Hauser. 2013. An equivalent soil mass procedure for monitoring soil organic carbon in multiple soil layers. European Journal of Soil Science 64: 58-65. https://doi.org/10.1111/ejss.12002

USDA PLANTS. 2020. Welcome to the PLANTS Database. Available from: https://plants.sc.egov.usda.gov/java/. Accessed May 7, 2020.

West, A.W. and G. P. Sparling. 1986. Modifications to the substrate-induced respiration method to permit measurement of microbial biomass in soils of differing water contents. Journal of Microbiological Methods 5: 177-189. https://doi.org/10.1016/0167-7012(86)90012-6

Xiao, Q., E. G. McPherson, J. R. Simpson, and S. L. Ustin. 1998. Rainfall interception by Sacramento's urban forest. Journal of Arboriculture 24: 235-244.

This article is protected by copyright. All rights reserved 
Table 1. Soil responses to site preparation and tree planting six years post-planting (2016) relative to baseline (2009) conditions (Q1). Here we report standardized coefficients ( \pm SE) to examine the compost by year (i.e., 2009 or 2016) interaction by testing the effect of year in plots with $(n=28)$ and without $(n=26)$ compost. We ran separate models for the two compost treatments because the strong interaction effects between this treatment and year suggested that soil responses to site preparation and tree planting were dependent on the addition of compost (Appendix S1: Table S1). Significant $(P<0.05)$ and marginally significant $(P<0.1)$ coefficients are shown in bold and italic fonts, respectively.

\begin{tabular}{|c|c|c|c|c|c|}
\hline & & Standardized $\mathrm{m}$ & l coefficients & & \\
\hline & Intercept & $\begin{array}{c}\text { Year } \\
\text { (2009 versus } \\
2016)\end{array}$ & Texture $^{+}$ & $\left(\text {Texture }^{+}\right)^{2}$ & $\begin{array}{l}\text { Fixed } R^{2} \\
\text { (Full) }\end{array}$ \\
\hline$p H$ & & & & & \\
\hline Compost & $7.6 \pm 0.093$ & $-0.28 \pm 0.060$ & $-0.24 \pm 0.13$ & $-1.2 \pm 0.28$ & $60(82)$ \\
\hline No Compost & $7.5 \pm 0.099$ & $-0.017 \pm 0.055$ & $-0.010 \pm 0.16$ & $-0.42 \pm 0.24$ & $10(78)$ \\
\hline $\begin{array}{l}\text { Microbial biomas } \\
\left(\mu g C g \text { soil }^{-1} h^{-1}\right)\end{array}$ & & & & & \\
\hline Compost & $1.3 \pm 0.053$ & $0.42 \pm 0.074$ & $0.026 \pm 0.074$ & - & $40(40)$ \\
\hline No Compost & $1.3 \pm 0.052$ & $0.15 \pm 0.073$ & $0.025 \pm 0.074$ & - & $7.4(7.4)$ \\
\hline$\%$ Carbon & & & & & \\
\hline Compost & $5.1 \pm 0.33$ & $1.8 \pm 0.34$ & $-0.66 \pm 0.56$ & - & $26(60)$ \\
\hline No Compost & $5.4 \pm 0.31$ & $-0.21 \pm 0.26$ & $-0.26 \pm 0.56$ & - & $1.0(63)$ \\
\hline$\%$ Nitrogen & & & & & \\
\hline Compost & $0.23 \pm 0.020$ & $0.23 \pm 0.018$ & $-0.048 \pm 0.035$ & - & $58(83)$ \\
\hline No Compost & $0.25 \pm 0.014$ & $0.049 \pm 0.012$ & $-0.023 \pm 0.026$ & - & $12(69)$ \\
\hline $\begin{array}{l}\% \text { Water holding } \\
\text { capacity }\end{array}$ & & & & & \\
\hline Compost & $30 \pm 0.71$ & $7.6 \pm 0.77$ & $-2.0 \pm 1.20$ & - & $55(74)$ \\
\hline No Compost & $30 \pm 0.78$ & $4.8 \pm 0.82$ & $-0.58 \pm 1.3$ & - & $26(59)$ \\
\hline Bulk density ( $\mathrm{g}$ cn & & & & & \\
\hline Compost & $1.4 \pm 0.070$ & $-0.44 \pm 0.076$ & $0.063 \pm 0.11$ & - & $31(58)$ \\
\hline No Compost & $1.3 \pm 0.055$ & $-0.43 \pm 0.068$ & $0.017 \pm 0.085$ & - & $38(50)$ \\
\hline $\begin{array}{l}\text { Soil carbon stock } \\
\text { (kg C m-2 at } 2.5 k \\
\text { soil depth) }\end{array}$ & & & & & \\
\hline Compost & $4.8 \pm 0.27$ & $0.80 \pm 0.24$ & $-0.39 \pm 0.48$ & - & $10(66)$ \\
\hline No Compost & $4.8 \pm 0.28$ & $-0.55 \pm 0.20$ & $0.00050 \pm 0.53$ & - & $3.4(76)$ \\
\hline
\end{tabular}

${ }^{+}$The soil texture metric used is the ratio of coarse to fine particles calculated as $\%$ sand/(\% clay $+\%$ silt $)$

This article is protected by copyright. All rights reserved 
Table 2. Standardized coefficients $( \pm \mathrm{SE})$ for the linear mixed models used to assess soil responses to the experimental treatments from one- (2011) to six-(2016) years post-planting (Q2). The three experimental treatments include compost amendments (presence or absence), interplanting with shrubs (presence or absence), and tree species composition (two or six species). Soil compost amendments consistently improved soil conditions through time in the afforestation site whereas the long-term effects of the shrub and composition treatments were minimal. Significant $(P<0.05)$ and marginally significant $(P<0.1)$ coefficients are shown in bold and italic fonts, respectively.

\begin{tabular}{lcccccc}
\hline & \multicolumn{5}{c}{ Soil Response Variable } \\
\cline { 2 - 7 } Variable & $\mathrm{pH}$ & $\begin{array}{c}\text { Microbial } \\
\text { biomass }\end{array}$ & $\begin{array}{c}\% \\
\text { Carbon }\end{array}$ & $\begin{array}{c}\text { \% } \\
\text { Nitrogen }\end{array}$ & $\begin{array}{c}\text { \% Water } \\
\text { holding } \\
\text { capacity }\end{array}$ & $\begin{array}{c}\text { Bulk } \\
\text { density }\end{array}$ \\
\hline Intercept & $\mathbf{7 . 5} \pm \mathbf{0 . 1 3}$ & $\mathbf{1 . 4} \pm \mathbf{0 . 0 5 8}$ & $\mathbf{6 . 2} \pm \mathbf{0 . 4 6}$ & $\mathbf{0 . 3 1} \pm \mathbf{0 . 0 2 3}$ & $\mathbf{3 4} \pm \mathbf{0 . 8 5}$ & $\mathbf{0 . 8 1} \pm \mathbf{0 . 0 4 0}$ \\
Year & $0.033 \pm 0.071$ & $0.025 \pm 0.11$ & $\mathbf{- 2 . 0} \pm \mathbf{0 . 5 4}$ & $-0.019 \pm 0.016$ & $\mathbf{3 . 5} \pm \mathbf{0 . 7 8}$ & $\mathbf{0 . 1 4} \pm \mathbf{0 . 0 4 3}$ \\
Compost & $\mathbf{- 0 . 5 5} \pm \mathbf{0 . 1 2}$ & $\mathbf{0 . 3 2} \pm \mathbf{0 . 0 5 6}$ & $0.89 \pm 0.53$ & $\mathbf{0 . 1 7} \pm \mathbf{0 . 0 2 6}$ & $\mathbf{3 . 4} \pm \mathbf{0 . 9 7}$ & $-0.033 \pm 0.046$ \\
Shrub & $-0.11 \pm 0.11$ & $0.0037 \pm 0.052$ & $-0.48 \pm 0.50$ & $-0.033 \pm 0.024$ & $-0.95 \pm 0.92$ & $0.020 \pm 0.043$ \\
Composition* & $0.16 \pm 0.12$ & $-0.095 \pm 0.055$ & $0.014 \pm 0.52$ & $0.0019 \pm 0.026$ & $-0.88 \pm 0.97$ & $0.041 \pm 0.045$ \\
Year x Compost & $\mathbf{0 . 3 3} \pm \mathbf{0 . 0 6 8}$ & $-0.13 \pm 0.11$ & $\mathbf{1 . 9} \pm \mathbf{0 . 6 0}$ & $-0.00014 \pm 0.018$ & $\mathbf{- 2 . 1} \pm \mathbf{0 . 8 7}$ & $\mathbf{0 . 1 1} \pm \mathbf{0 . 0 4 8}$ \\
Year x Shrub & $-0.054 \pm 0.066$ & $-0.13 \pm 0.11$ & $0.29 \pm 0.58$ & $0.010 \pm 0.017$ & $0.069 \pm 0.84$ & $0.039 \pm 0.046$ \\
Year x Composition ${ }^{*}$ & $0.032 \pm 0.068$ & $0.070 \pm 0.11$ & $0.036 \pm 0.60$ & $0.00086 \pm 0.018$ & $1.4 \pm 0.87$ & $-0.0044 \pm$ \\
Texture & & & & & & 0.048 \\
Fixed $R^{2}$ (Full) & $-0.23 \pm 0.12$ & $-0.0046 \pm 0.054$ & $-0.83 \pm 0.52$ & $-0.048 \pm 0.025$ & $-1.4 \pm 0.95$ & $0.049 \pm 0.045$ \\
\hline
\end{tabular}

${ }^{*}$ The categorical composition variable is analyzed as a shift from two- to six-species plots in the regression analysis.

${ }^{+}$The soil texture metric used is the ratio of coarse to fine particles calculated as $\% \mathrm{sand} /(\%$ clay $+\%$ silt) 
Table 3. Standardized coefficients $( \pm \mathrm{SE})$ for the linear mixed models (LMMs) used to analyze the association between soil conditions and planted tree growth (basal area in $\mathrm{m}^{2} \mathrm{ha}^{-1}$ ) for Tilia americana, Quercus rubra, and for both species combined (Q3). Microbial biomass exhibited a nonlinear, unimodal relationship with tree size, so coefficients for the positive and negative direction of microbial biomass are denoted by $(+)$ and $(-)$, respectively. We used hydrogen ion concentration $\left[\mathrm{H}^{+}\right]$ in lieu of $\mathrm{pH}$ in the LMMs since it is on a linear rather than logarithmic scale. We analyzed changes in each variable in the subset of plots with $(n=26)$ and without $(n=28)$ compost based on strong soil responses to this particular treatment. For the full model $(n=54)$ results, see Appendix S1: Table S2. Significant $(P<0.05)$ and marginally significant $(P<0.1)$ coefficients are shown in bold and italic fonts, respectively. Initial diameter of root collar (DRC) was used to account for variation in sapling size on planting.

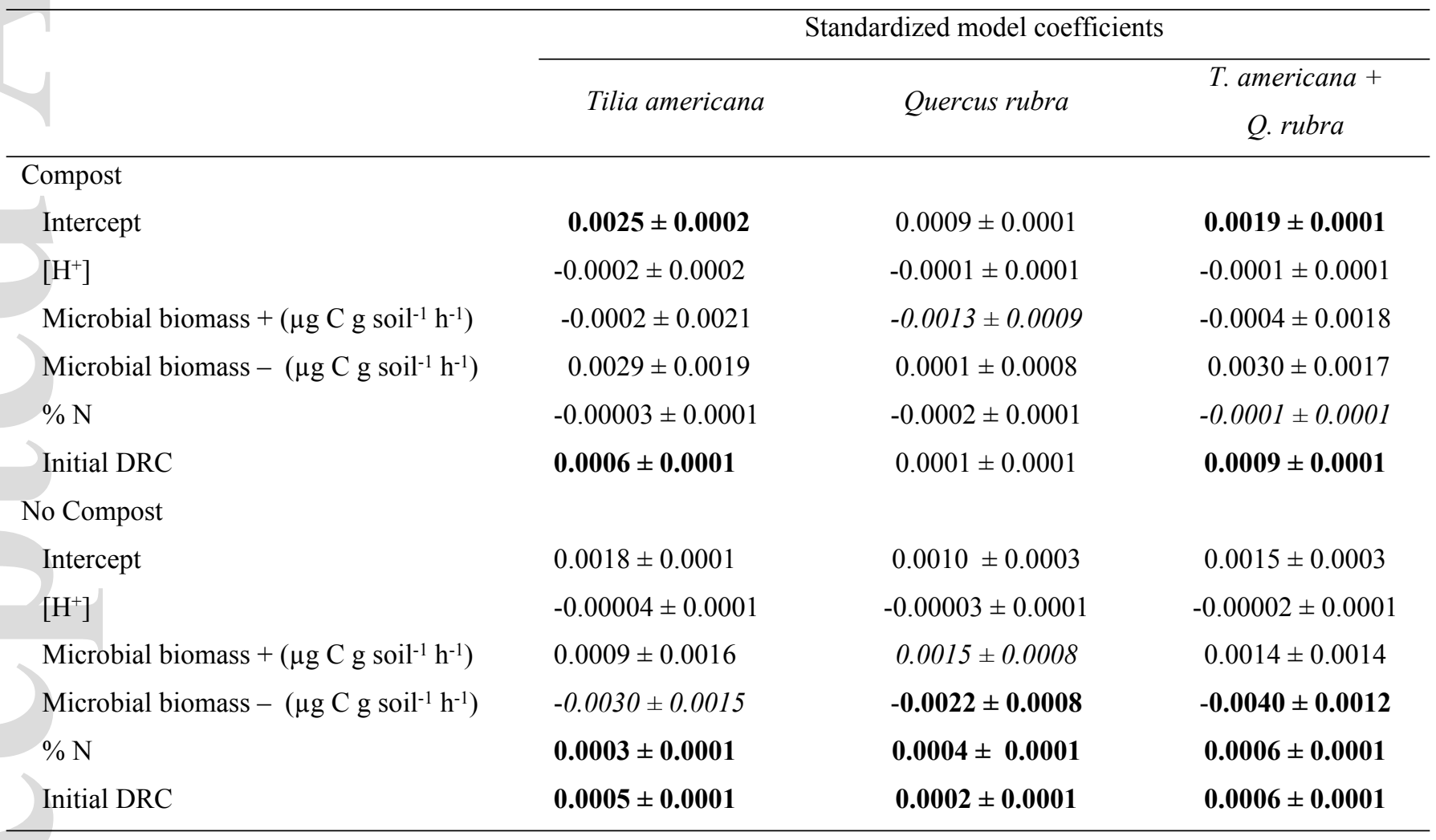

This article is protected by copyright. All rights reserved 


\section{Figure Legends}

Figure 1. Map of the 54 experimental plot locations and their compost treatments (amended or unamended) in Kissena Corridor Park, Queens, New York City, USA (a) and the plot layout for the species composition (two and six species) and shrub (with or without shrubs) treatments (b). All 54 plots were planted with either two or six tree species, and the species composition treatment was crossed with the shrub and soil amendment treatments. Sampling occurred in the interior plot, which was surrounded by a $2.5-\mathrm{m}$ buffer of planted trees to minimize the influence of edge effects. Figure modified from Felson et al. (2013).

Figure 2. Effects of site preparation (i.e., tilling, weeding, mulch application), afforestation, and the three experimental treatments (compost amendments, interplanting with shrubs, and tree species composition) on soil conditions over time. Compost-amended plots sustained larger soil responses than unamended plots for all measured variables (a-e) except bulk density (f). The horizontal dashed lines and shaded areas show mean baseline values and 95\% confidence intervals. The double-dashed (red) and solid (gray) lines are used to help visualize directional trends in mean values over time for amended and unamended plots, respectively, and are not intended to represent interpolated data. Circles indicate the mean values for each year, and the error bars show the $95 \%$ confidence intervals, which are normalized to account for repeated measures of the same plot (see Methods). Compostamended plots are shown in red and unamended plots are gray; six-species plots are triangular and two-species plots are square-shaped; and plots with shrub plantings are filled and plots without shrubs are unfilled. 
a)
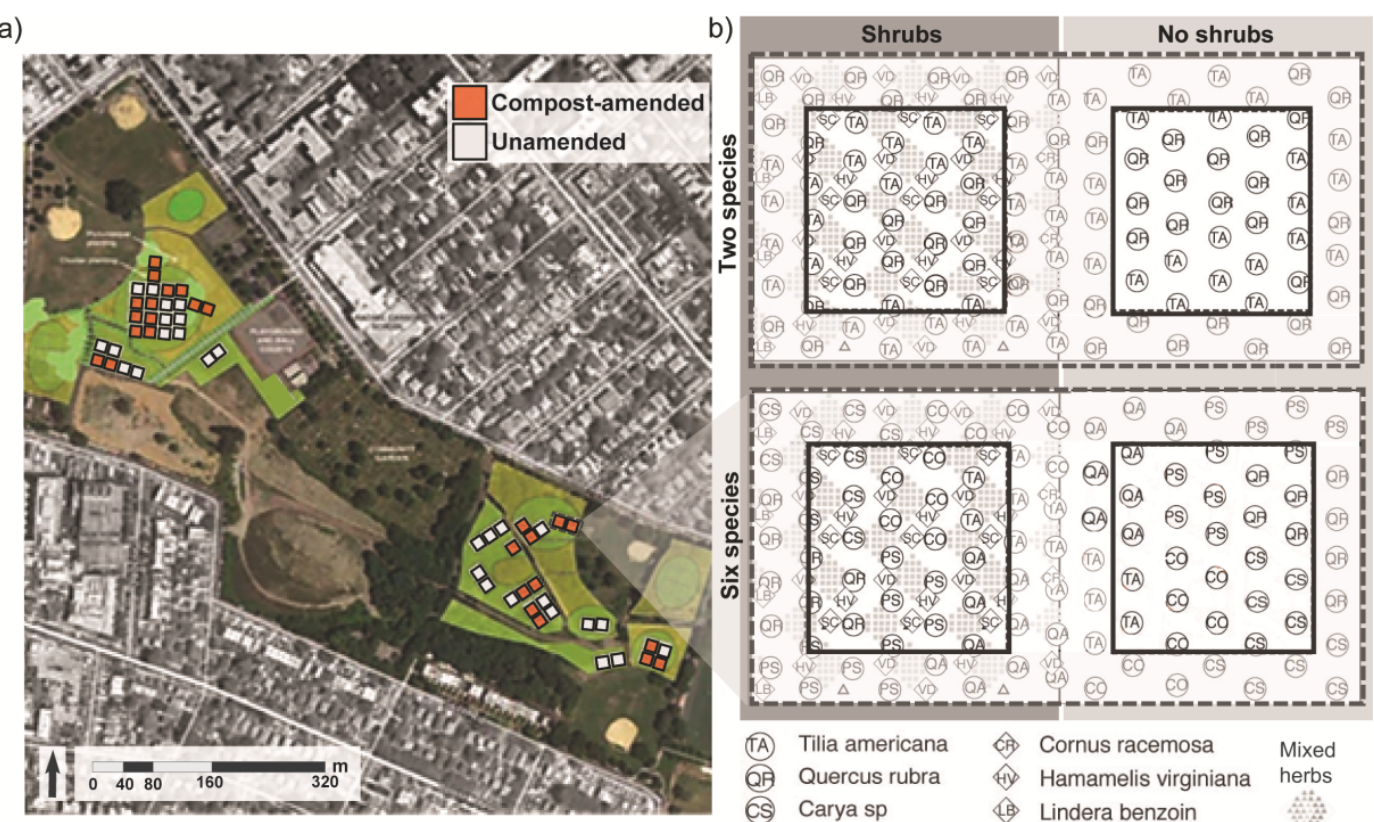

(tA) Tilia americana

Q8) Quercus rubra

cS) Carya sp

(e) Prunus serotina

(QA) Quercus alba

ø. Celtis occidentalis

kaly Cornus racemosa

Mixed

(1) Lindera benzoin

(s) Sambucus canadensis

vig. Viburnum dentatum

eap_2336_f1.tif 

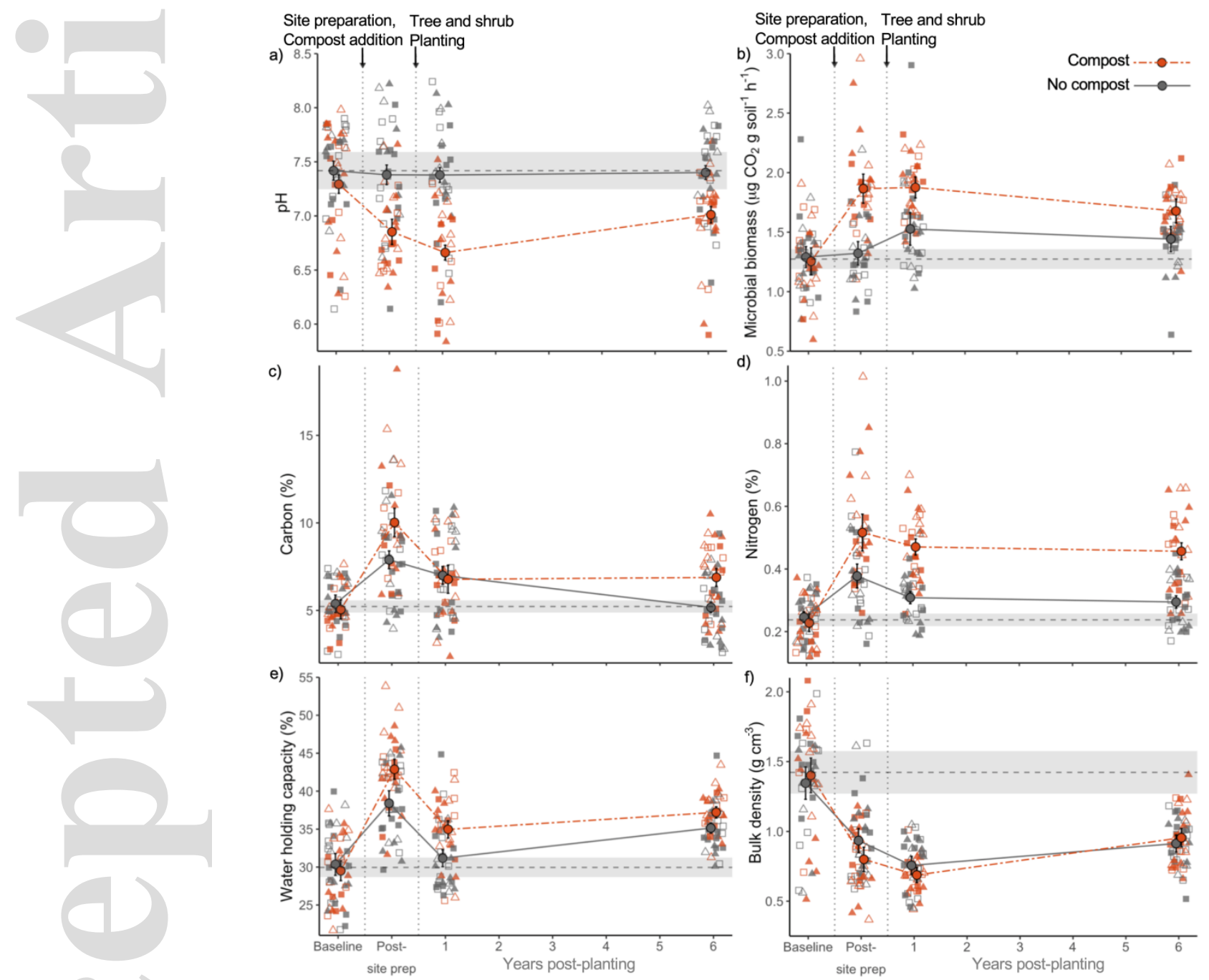

eap_2336_f2.tif 